\title{
Circular Cities: What Are the Benefits of Circular Development?
}

\author{
Jo Williams
}

check for

updates

Citation: Williams, J. Circular Cities: What Are the Benefits of Circular Development?. Sustainability 2021, 13, 5725. https://doi.org/10.3390/su 13105725

Academic Editor: Miguel Amado

Received: 19 March 2021

Accepted: 16 May 2021

Published: 20 May 2021

Publisher's Note: MDPI stays neutral with regard to jurisdictional claims in published maps and institutional affiliations.

Copyright: (C) 2021 by the author. Licensee MDPI, Basel, Switzerland. This article is an open access article distributed under the terms and conditions of the Creative Commons Attribution (CC BY) license (https:// creativecommons.org/licenses/by/ $4.0 /)$.
Director of the Circular Cities Hub, Bartlett School of Planning, University College London, London WC1H0NN, UK; joanna.williams@ucl.ac.uk

\begin{abstract}
If cities could become regenerative and adaptive urban ecosystems, in which resource loops were closed and waste was obsolete, their ecological footprint would diminish. In addition, urban resource security would increase, the health of urban populations would improve and urban greenhouse gas emissions would be reduced. These are the principle goals under-pinning the circular city. Circular cities emerge through the process of circular development. Circular development alters cities' systems of provision to enable circular practices of inhabitants to develop. This manifests as circular food systems and construction, water and nutrient recycling; adaptive reuse of spaces and pop-up activities; bioremediation of contaminated sites and integration of blue-green infrastructure throughout cities. To transform our cities will require significant investment, political support and public engagement. If the benefits of adopting such an approach can be identified, this will begin to make the case for support. The research presented in this paper draws on an inductive and deductive content analysis of relevant literature and interviews with those implementing circular projects in European cities (London, Paris, Amsterdam and Stockholm). It provides a clear definition of the normative concept of circular development. It creates a framework of benefits which are likely to accrue from adopting this approach. It points to the synergistic benefits emerging from circular development. It also highlights problems around valuation of those benefits, the unintended consequences of circular development and the inequalities in accessing benefits across society.
\end{abstract}

Keywords: circular economy; regenerative cities; adaptive cities; sustainability benefits; sustainable development

\section{Introduction}

Currently cities consume $60-80 \%$ of the world's natural resources and produce $50 \%$ of global waste. They also emit $75 \%$ of global greenhouse gas emissions [1]. Thus, they are major contributors to global resource depletion, waste mountains and climate change. Urban resource security issues are also increasingly a problem, particularly for water, food and energy [2-4]. This is further exacerbated by climate change. The health of urban ecosystems is also declining, resulting in flooding, drought, heating, pollution, reduced biodiversity, loss of vegetation and soil degradation. These problems impact on the urban economy and the health of urban populations.

If cities could become regenerative and adaptive urban ecosystems, in which resource loops were closed and waste was obsolete, their ecological footprint would diminish. In addition, urban resource security would increase, the health of urban populations would improve and urban greenhouse gas emissions would reduce. These are the principle goals under-pinning the circular city. Circular cities emerge through the process of circular development. Circular development alters cities' systems of provision-urban infrastructure, processes and activities - to enable the circular practices of inhabitants to develop. Thus, a circular development approach to the regeneration and renewal of our cities, could help address these problems. The paper analyzes the evidence for this claim.

To date, much of the literature has concentrated on a narrow view of the circular economy, which focuses on improving the resource efficiency of supply chains and production processes to maximize economic savings for industry [5-8]. Within this literature, circular 
cities are defined as those in which urban industrial actors adopt closed-loop production processes and business models [9]. Urban systems of provision (energy, water, transport), the social practices and lifestyles of those living in cities which affect resource consumption, are overlooked. In terms of the sustainable development goals, the focus is on responsible production, industrial innovation and economic development.

In contrast, circular development is a new normative model for urban development, conceived by the author and reported elsewhere [9-11], which focuses on the processes creating the infrastructure and urban activities supporting circular urban systems. These systems are natural, social and artificial, supporting technospheric, biospheric and socioeconomic cycles. Circular development allows cities to adapt to shocks and long-term changes in the wider landscape, with minimal ecological impact. It aims to reduce urban resource consumption (materials, land, water, infrastructure and energy), waste and greenhouse gas emissions (GHGs), whilst regenerating the urban ecosystem and building urban resilience $[10,11]$. Circular development enables the healthy renewal of cities. It could also help to deliver many of the sustainable development goals.

In circular cities, three actions - resource looping, adaptation and ecological regenerationare implemented in combination to deliver circular development. Figure 1 illustrates some of the processes, activities and material manifestations of circular development in cities. Resource looping (reuse, recycling and recovery) is encouraged through the provision of circular infrastructural systems (e.g., gray-water recycling systems, recyclable infrastructure) and the introduction of new circular processes (e.g., conversion of organic waste to energy, biochemicals or feedstock) in cities. Urban form may also alter to accommodate these new activities, for example through the provision of space to store recyclates or reusable objects. Changes in local systems of provision (e.g., local food banks, recycling websites, repair workshops) also encourage urban inhabitants to reuse and recycle resources.

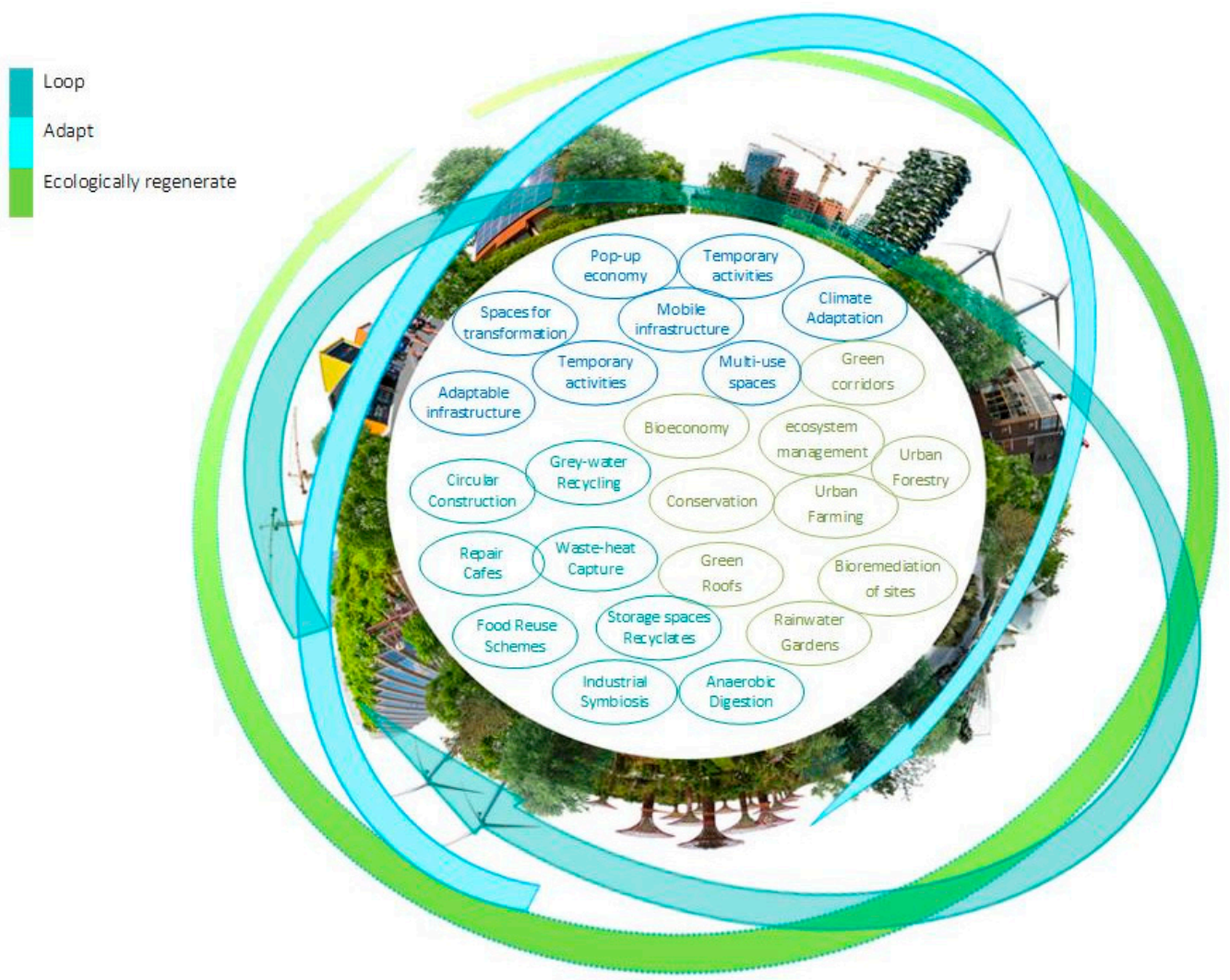

Figure 1. Circular development (Source: Author's own).

Circular development produces adaptable cities, offering space to transform (e.g., pop-up spaces) and grow, and infrastructure (e.g., scalable, movable, refit-able, flexible) that 
evolves with changing needs. It also introduces processes (e.g., collaborative planning, coprovision, tactical urbanism) which support learning within communities and encourage self-organization. Urban experiments (often pop-up activities) provide an opportunity to test new circular systems of provision and enable communities to quickly adapt to changing contexts. This adaptiveness enables infrastructure and communities to transform to meet the new demands placed on them, thus increasing urban resilience.

Circular development also protects and enhances urban ecosystem services, which reinforce natural cycles and improve the health of those living in cities. Ecologically regenerative actions are often operationalized through the inclusion of green and blue infrastructure in the urban fabric, the management of urban ecosystems (e.g., water management, conservation, farming, forestry) and bioremediation processes (e.g., phytoremediation of contaminated urban sites).

The process of implementing circular development in our cities is likely to be costly and disruptive. It will require a wholesale shift in the way we plan, design and manage our cities. It will necessitate changes in social practices, lifestyles and systems of provision. Support for this transformation will be needed, from politicians, service providers and the public, if it is to be successful. To gain support, the benefits of adopting this approach will need to be clear. Examples of circular urban development have already emerged in European cities. The introduction of the new Green Deal in Europe is galvanizing more cities to join them. Thus, there is an expanding evidence base which we can analyze to determine the benefits of adopting the approach. There is also an imperative to do so, as funding is provided to support this transformation.

This paper contributes theoretically to the urban sustainability and circular cities literature. Firstly, it provides an analysis of the potential ecological, social and economic benefits (and disbenefits) of urban circular development. Secondly, it supplies initial evidence of the synergistic benefits created through combining the three circular actions in cities, rather than applying them separately. Thirdly, it identifies the potential benefits of adopting specific circular urban systems (e.g., circular construction, circular food systems, water and nutrient systems) using examples from 4 European cities. Finally, the paper highlights important issues around the fair evaluation of the benefits identified, the unintended consequences of circular development and inequalities in accessing the benefits of circular development across society.

The paper begins by introducing the research methodology (Section 2). It presents the results from an inductive content analysis of academic and gray literature, which generated a framework of the potential benefits of adopting the three circular actions (Section 3). It goes on to introduce the four case study cities, in which examples of circular development have been implemented (Section 4). The benefits which emerged from these examples, were identified through a mixture of expert interviews and reviews of relevant gray literature, which are presented in Section 5. The findings of both analyses are discussed in Section 6. This section also highlights some of the problems associated with circular development.

\section{Aims and Methods}

The aim of the first stage of the research was to identify the benefits (and disbenefits) of adopting a circular development approach in cities. A systematic analysis of Scopus' indexed publications and research-based, technical reports (published by reputable consultancies) was completed in 2020 to determine the benefits. Three inclusion criteria were used: relevance (papers focused on circular development actions in cities-see the search terms in Table 1), language (publication in English) and validity (a peer-reviewed article or technical report published by a reputable consultancy). 
Table 1. Search terms for circular development.

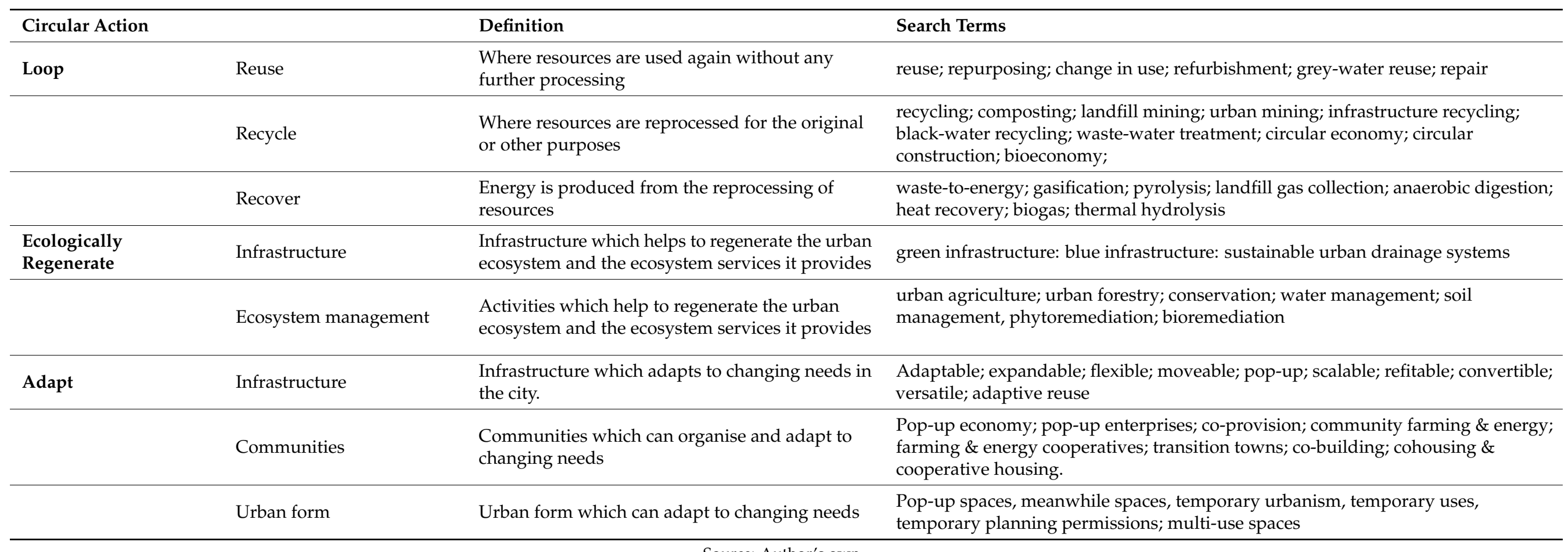


Over 300 documents were reviewed. The papers appeared to segregate into three categories, reflecting the three circular actions: looping actions and circular economy; ecological regeneration and nature-based solutions; urban resilience and adaptationwith some overlap. Two sets of search terms were used to identify relevant papers. The first set referred to the urban focus ("cities" and "urban") and the second set to circular development actions (see Table 1 for terms searched for circular actions).

There were many query strings used. For example, the query string for reuse would be "cities" OR "urban" AND "reuse" OR "repurpose" OR "refurbishment". The search identified 214 potentially relevant papers with key words and abstract text matching the queries.

An inductive content analysis (using NVIVO) was then completed to identify the benefits of adopting circular development in cities. Open coding was used to identify benefit categories and clusterings across the literature (and reduce bias). Initial full text reads immersed the researcher in the literature, enabling her to gain a sense of all the benefits emerging from circular development. The second reading was used to derive an initial set of codes. These codes were sorted into categories and coding tree diagram was created. Three benefit categories (ecological, economic and social benefits) emerged (Table 2). These categories were then used to organize and group codes. In total, 33 coding themes emerged: 12 ecological, 10 economic and 11 social benefits. The social category subdivided into two themes: health and community benefits.

Table 2. Coding framework-benefits of circular development.

\begin{tabular}{|c|c|c|c|}
\hline Categories & Sub Themes & Codes & Sub-Codes \\
\hline \multirow{6}{*}{ Ecological Benefits } & & Reduce consumption & Water, material, energy, land \\
\hline & & Ecosystem Services & regulation provisioning, support, cultural \\
\hline & & Reduce greenhouse gas emissions & - \\
\hline & & resource sufficiency & - \\
\hline & & Adapt to environment change & - \\
\hline & & $\begin{array}{l}\text { Increase environmental } \\
\text { Awareness }\end{array}$ & - \\
\hline \multirow{7}{*}{ Social Benefits } & Health & Health benefits & $\begin{array}{l}\text { Physical health, mental health, stress, nutrition, } \\
\text { obesity, longevity }\end{array}$ \\
\hline & \multirow{6}{*}{ Community } & Builds local symbiotic capital & - \\
\hline & & Empowers communities & - \\
\hline & & Stabilizes existing communities & - \\
\hline & & Opportunities to socialize & - \\
\hline & & Access to resources for the excluded & $\begin{array}{l}\text { Affordable heat, food, goods, accomodation, } \\
\text { energy }\end{array}$ \\
\hline & & Increases community resilience & - \\
\hline \multirow{10}{*}{ Economic Benefits } & & Creates jobs & - \\
\hline & & Avoid costs & Health, insurance, landfill \\
\hline & & Creates economic value & - \\
\hline & & new industrial sectors and businesses & - \\
\hline & & removes redundancies & $\begin{array}{l}\text { Vacancies, undeveloped sites, "waste", } \\
\text { ineffieciencies in production processes }\end{array}$ \\
\hline & & Reduces supply and production costs & - \\
\hline & & Activates vacant and unused spaces & - \\
\hline & & Increases value of properties and land & - \\
\hline & & Localized value chain & - \\
\hline & & Localized production & - \\
\hline
\end{tabular}


The second stage of the research identified the benefits accrued from adopting circular urban systems in four European cities: Amsterdam, Paris, London and Stockholm. These cities were chosen because they are pioneers in implementing circular systems of provision and offer well-established examples [11]. They have engaged in implementation, over a longer period and thus have a richer understanding of the benefits emerging. Therefore, the data collected is better informed. The cities offered a diversity of circular urban systems including: circular construction and food systems; adaptive reuse of spaces and infrastructure; water and nutrient recycling systems; waste heat recovery and waste-to-energy systems; ecological restoration systems (bioremediation, environmental management, integration of blue-green infrastructure). These represent the most common circular systems found in European cities. Thus, they provide a representative sample.

Primary data was collected through 52, one-to-one, key stakeholder interviews with providers of services and infrastructure who had implemented circular systems within those cities (Table 3). A range of representative stakeholders were interviewed across the private, public and community sectors. These interviews took place during the period June 2017-June 2019 and lasted between 40-60 $\mathrm{min}$. Open ended questions were posed to reduce bias. For example, "In your experience, what benefits emerged from adopting this circular system/process/project". Open ended probes were used to follow-up the respondents' answers. For example, "can you provide more information illustrating these benefits". In addition, interviewees were asked to identify instances where synergistic benefits emerged from adopting circular actions. The interviews were recorded and transcripts were generated. Where possible, responses were corroborated by studies measuring the actual benefits of circular systems provided by technical reports (to increase reliability).

Table 3. Key stakeholder interviews.

\begin{tabular}{|c|c|c|c|c|c|c|}
\hline Group & Type & $\begin{array}{c}\text { Number Stakeholders } \\
\text { Interviewed }\end{array}$ & Amsterdam & Paris & London & Stockholm \\
\hline \multirow{9}{*}{ Private } & Developer & 4 & $x$ & $x$ & $x$ & $x$ \\
\hline & Construction manager & 2 & $x$ & & $x$ & \\
\hline & Engineering/planning consultant & 3 & $x$ & & $x$ & $x$ \\
\hline & Architect & 1 & & & & $x$ \\
\hline & $\begin{array}{l}\text { Landscape architect/green infrastructure } \\
\text { consultant }\end{array}$ & 3 & & $x$ & $x$ & $\mathrm{x}$ \\
\hline & Water and waste water engineer & 4 & $x$ & $x$ & $x$ & $x$ \\
\hline & Industrialist & 2 & $x$ & & $x$ & \\
\hline & Temporary use consultant & 2 & & $x$ & $x$ & \\
\hline & Property consultant & 2 & & $x$ & $x$ & \\
\hline \multirow{6}{*}{ Public } & Local politician & 4 & $x$ & $x$ & $x$ & $x$ \\
\hline & Strategic planner & 4 & $x$ & $x$ & $x$ & $x$ \\
\hline & Economic development officer & 4 & $x$ & $X$ & $x$ & $x$ \\
\hline & Circular economy officer & 2 & $x$ & & $x$ & \\
\hline & Sustainable development officer & 3 & $x$ & & $x$ & $x$ \\
\hline & Ecologist & 1 & & & $x$ & \\
\hline \multirow{5}{*}{ Community } & Academic & 4 & $\mathrm{x}$ & $x$ & $x$ & $\mathrm{x}$ \\
\hline & Circular economy/waste recycling foundations & 1 & & & $x$ & \\
\hline & Conservationists & 1 & & & $X$ & \\
\hline & Social enterprises & 2 & & $x$ & $x$ & \\
\hline & Urban farmers & 2 & & $x$ & $x$ & \\
\hline Total & & 52 & 11 & 11 & 19 & 10 \\
\hline
\end{tabular}


This provided an understanding of the perceived benefits of circular development amongst those implementing it. The interview transcripts were read by the researcher to gain an overview of the responses. Notes of the benefits reported were made for each transcript. A comparison was made between the initial codes emerging from the interviews and those from the literature. The same categories were emerging. Thus, the results from the interviews validated the benefits framework produced by the initial inductive content analysis of the literature. The interviews were then analyzed with NVIVO, using the coding framework developed from the first stage of the analysis (Figure 2). Various search terms were then used to analyze the transcripts (Table 4).

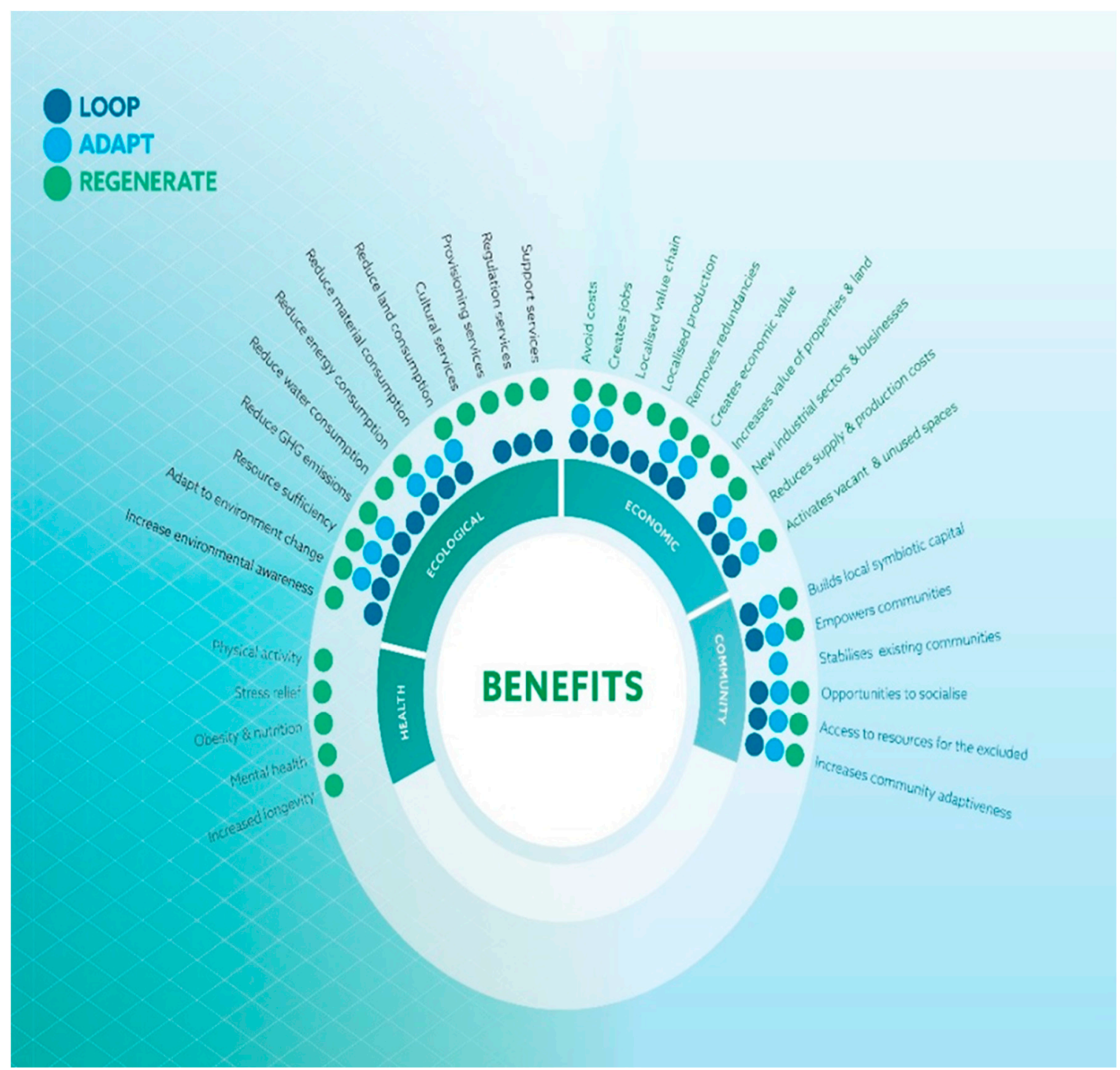

Figure 2. Benefits of adopting circular development in cities (Source: Author's own). 
Table 4. Key stakeholder interviews-themes, codes and search terms.

\begin{tabular}{|c|c|c|c|}
\hline Theme & Code & Sub-Code & Search Terms \\
\hline \multirow{6}{*}{ Ecological Benefits } & Reduce consumption & Water, material, energy, land & "reduce consumption" AND "water" OR "material" OR "land OR "energy" \\
\hline & Ecosystem Services & regulation provisioning, support, cultural & $\begin{array}{l}\text { "ecosystem services" AND "regulation" OR "provisioning" OR "support" OR } \\
\text { "cultural" }\end{array}$ \\
\hline & Reduce greenhouse gas emissions & - & "greenhouse gas emissions" OR " climate mitigation" \\
\hline & resource sufficiency & - & "resource security" OR "resource sufficiency" \\
\hline & Adapt to environment change & - & " urban adaptation" OR "climate adaptation" OR "adaptive systems" \\
\hline & $\begin{array}{l}\text { Increase environmental } \\
\text { awareness }\end{array}$ & - & "environmental awareness" OR "pro-environmental behaviour" \\
\hline \multirow{6}{*}{ Social Benefits } & Health benefits & & $\begin{array}{l}\text { " health benefits" OR "physical health" OR "stress relief" OR "obesity " OR " good } \\
\text { nutrition" OR "mental health" OR "increased life-span" }\end{array}$ \\
\hline & Builds local symbiotic capital & - & $\begin{array}{l}\text { " local capital" OR "social capital" OR human capital" OR "financial capital" OR } \\
\text { "physical capital" OR "natural capital" }\end{array}$ \\
\hline & Empowers communities & - & "community empowerment" \\
\hline & Stabilizes existing communities & - & Community AND "stabilisation" OR "retention" \\
\hline & Opportunities to socialize & - & "social events" OR "social opportunities" \\
\hline & Increases community resilience & - & $\begin{array}{l}\text { "resilience" OR "adaptive capacity" OR "community organisation" OR } \\
\text { "community learning" OR " sufficiency" }\end{array}$ \\
\hline \multirow{9}{*}{ Economic Benefits } & Creates jobs & - & "jobs" OR “employment" \\
\hline & Creates economic value & - & "valorisation" OR "economic return" \\
\hline & new industrial sectors and businesses avoid costs & - & "new industries" OR "new businesses" \\
\hline & removes redundancies & - & "redundancies" OR “vacant" OR "waste" \\
\hline & Reduces supply and production costs & - & "supply costs" OR "production costs" \\
\hline & Activates vacant and unused spaces & - & "site reuse" or "regeneration" or "renewal" \\
\hline & Increases value of properties and land & - & "land values" OR "property values" \\
\hline & Localized value chain & - & "local value chain" \\
\hline & Localized production & - & "local production" \\
\hline
\end{tabular}




\section{The Sustainability Benefits of Circular Development}

This section summarizes the findings of the inductive content analysis of the literature and illustrates the benefits of the three circular actions identified using examples from key texts. The analysis suggests many sustainability benefits will accrue from adopting a circular development pathway. The benefits framework produced from the analysis is presented in Figure 2.

\subsection{Ecological Benefits}

The inductive content analysis highlighted 12 ecological benefits associated with adopting circular development in cities. Broadly, these fall into five categories: reducing resource consumption (energy, water, materials and land); restoring urban ecosystem services; reducing greenhouse gas emissions; increasing urban capacity to adapt to climate change; and increasing environmental awareness amongst the public.

All three circular actions contributed to a reduction in urban resource consumption (energy, materials, water and land). For example, reusing heat emitted from buildings and anaerobic digestion of organic waste, reduces fossil fuels consumed [12]. The adaptive reuse of buildings bypasses the wasteful process of demolition and reconstruction whilst producing energy savings [13]. Green infrastructure can reduce air and surface temperature in cities, thus reducing energy used for air conditioning [14]. Gray-water recycling and reuse combined with rainwater collection and storage in blue-green infrastructure reduces consumption of potable water for non-drinking purposes [15,16]. Overall, a reduction in resource use can also increase resource security within urban systems.

Circular actions also improved the health of urban ecosystem services. Looping and ecologically regenerative actions helped to restore urban ecosystem services essential for tackling pollution [17]; supporting carbon sequestration; regulating local climate [18]; managing hydrology [19]; increasing biodiversity and producing fertile soils in cities. The restoration of ecosystem services also supports local resource production (e.g., food, fuel). It provides clean water and air, which are essential for a healthy population. It also provides access to areas for recreation $[14,15,20]$.

All three circular actions reduce greenhouse gas emissions [20-22]. Looping designs out waste, reducing greenhouse gas emissions across the value chain [22,23]. Thus, the reuse of steel in construction can reduce the carbon footprint of buildings [24] and the reuse of food reduces methane emitted from landfill [25]. Adaptation keeps infrastructure and materials in use to retain the embodied energy in both. For example, the adaptive reuse of infrastructure avoids the emissions generated by the demolition, fabrication, transportation and construction of buildings [26]. The regeneration of urban ecosystems aids in the sequestration of carbon in soil and vegetation $[14,27,28]$. It also increases urban capacity to adapt to climate change $[14,29,30]$.

Finally, localized looping (e.g., local circular food systems, community energy) and regenerative actions (e.g., community gardening, conservation projects, urban farming) heighten environmental awareness amongst the public [31,32]. However, increasing resource efficiency and resulting reduction in supply costs may also produce a rebound effect [33].

\subsection{Health Benefits}

The social benefits identified by the literature subdivided into two themes: health benefits and community benefits. The inductive content analysis highlighted that ecological regeneration produced significant health benefits in urban populations. Green infrastructure regulates local climate, water, noise and air pollution, all of which have a direct impact on the mental and physical health of those living in cities [34,35]. It could also increase the resilience of the urban population to pandemics (e.g., sars cov-2) by addressing the health co-morbidities (i.e., respiratory, cardiac problems, type II diabetes and obesity) that increase mortality rates amongst those with disease [36]. 
However, green spaces must be accessible (within $1 \mathrm{~km}$ of people's homes) to have a significant effect on the mental and physical health of urban inhabitants [34]. This is particularly important for children, the elderly and people from lower socio-economic groups, who spend the most time close to home. However, there is still a great deal of variation in access to green space across socio-economic groups in cities [37-39].

The provision of green infrastructure can also encourage active lifestyles amongst the wider population [40]. Green corridors with integrated active transport networks reinforce walking and cycling in cities [41,42]. Active lifestyles reduce obesity, levels of stress and improve the mental health of city dwellers, helping to build long-term health resilience [43-45].

\subsection{Community Benefits}

The inductive content analysis highlighted that all three circular actions help to strengthen and empower local communities, through the operation of community projects (e.g., energy and farming cooperatives; food-reuse and repair schemes). These projects build stronger social capital (social networks) and human capital (skills and experience) through people's engagement in circular actions [14,46,47]. For example, repair cafes: develop technical skills; reduce costs of goods for low income groups; provide meeting places and increase social cohesion within communities [48]. Similar benefits were identified amongst those engaged in community farming cooperatives [49]. However, community projects often encounter significant barriers to scaling up [48].

Community projects can also generate local economic (financial return) and physical capital (infrastructural systems supporting circular activities), which increase the resilience and adaptiveness of communities. For example, renewable energy cooperatives provide new infrastructure and generate economic capital, as well as encourage greater social cohesion and pro-environmental behavior [50,51]. Adaptively reused buildings also provide spaces for new pop-up activities. This form of tactical urbanism increases adaptiveness, creating more resilient and stable communities [52,53].

All three circular actions may also increase access to resources (e.g., goods, accommodation, heat, clean air, green spaces) in communities. For example, furniture reuse schemes have been shown to reduce hardship and help to build human capital [47]. However, in practice there is also evidence to suggest that the benefits of circular actions may not be experienced equally across communities. For example, green space is often less accessible to the urban poor [54]. Low income households are also less likely to participate in and benefit from urban farming projects [55].

\subsection{Economic Benefits}

Finally, the inductive content analysis highlighted 10 economic benefits, which could emerge from circular development, particularly in the circular, bio and pop-up economies. These focused on four key areas: reduced supply and production costs to producers; creation of economic value; diversification of the economy and job creation.

Looping actions can reduce supply and production costs by reducing "waste", using recyclates and localizing supply chains [56]. The circular economy will create new economic sectors, industries and businesses, thus generating new job opportunities $[22,56,57]$. Valorizing construction and organic waste streams appear to be particularly viable in city-regions.

Research suggests that the circular economy will require a heterogenous skills base, offering opportunities to all [58]. However, experience in India and China with informal waste recycling sectors suggest that poorer groups will tend to be employed in these less secure, poorly paid and potentially hazardous jobs. There is also disagreement over the scale of economic opportunities provided by the circular economy. The OECD suggests the opportunities maybe more modest than first predicted and will vary between countries [59].

Research indicates that the bioeconomy has the potential to address many sustainability goals [60]. The urban bioeconomy exploits latent urban assets in the form of biological 
models and processes for various direct or indirect economic benefits [60,61]. Two processes are integral to the bioeconomy. The first involves harnessing biological assets offered by ecosystem services (e.g., carbon sequestration, producing resources, reducing pollution and flooding, bioremediation). This process of ecological regeneration enhances land and property values. It can also bring brownfield sites back into use.

If ecosystem services are properly valued, ecological regeneration can be a source of value creation [62]. Ecosystem services can also help avoid health, flood and pollution remediation costs. Managing these biological assets, produces new resources and creates local employment opportunities in a range of areas: urban forestry, conservation, agriculture, energy, water management, carbon sequestration, recreation, health and tourism [63].

The second process focuses on the valorization of biological waste. This is the circular urban bioeconomy, which overlaps with activities in the circular economy. Biological waste is valorized through bio-prospecting or biological processes which reduce waste. New industrial sectors and businesses are already emerging in the bioeconomy, generating jobs [64]. In 2017, over 17 million people were employed in the European bioeconomy. This added EUR 614 billon to the European economy. Growth areas included bio-based electricity, biochemicals and forestry.

The pop-up economy could also make a significant contribution to economic growth. It has been estimated that pop-up activities are worth more than GBP 2.3 billion to the UK economy alone and employ over 26,000 people. The temporary nature of urban popup activities also increases a city's ability to adapt to changes in the landscape. Pop-up activities remove redundancies (e.g., vacant sites, properties, under-utilized utilities) in the urban system produced by economic shocks $[65,66]$.

Pop-up activities reactivate unused sites, enhancing local vitality, which increases local land values and revitalize the local economy $[20,65,67]$. This process extracts latent value from temporarily disused sites [68]. Tactical urbanism is a valuable urban model, which reduces economic risk, unlocks potential of sites and generates a capital flow [68]. However, the gentrification process associated with increasing value can also result in social exclusion.

The inductive content analysis clearly demonstrates the benefits of adopting circular actions in cities. It also begins to highlight some of the problems.

\section{European Examples of Circular Development}

To validate these findings, an analysis of the benefits emerging from the adoption of circular systems of provision across four European cities was completed. We begin here with a brief description of the four cities and the circular systems they have adopted.

\subsection{Amsterdam}

Amsterdam encourages a strategic, city-regional approach to resource looping, of construction and organic waste. The producers and users of "waste" are linked throughout the city-region. Smart data and online marketplaces are used to enable the exchange of construction "waste". Material passports, databases (e.g., CIRCLE SCAN which maps material flows and PUMA which identifies buildings in which reserves of valuable metals can be found) and resource banks (space for storing recyclates) facilitate the circular construction process. Public procurement (of recycled building materials), circular tendering and land release have also generated demand for recyclates in construction.

Organic waste is also looped within the city-region. Waste separation, smart reverse logistics and cascading organic waste flows, ensure the residual flows retain their highest value. The development of bio-refineries in the city region enable organic materials to be recycled or energy to be recovered locally and at scale. In addition, nutrients are recovered from residual food for reuse (by restaurants or foodbanks) or composting.

Amsterdam is also encouraging the emergence of neighborhood-scale, pop-up circular experiments. Vacant, often contaminated, municipally owned sites, are made available temporarily for circular experiments. De Ceuvel (Buiksloterham), is one such experi- 
ment, constructed on a contaminated site in the Port of Amsterdam. It adopts all three circular actions.

Houseboats have been adaptively reused for workshops, offices and a café. Phytoremediating plants have been used to decontaminate the soil on site. Off-grid, above surface infrastructure has been integrated into the development, to avoid sub-surface infrastructure from needing to be buried in contaminated land. Dry composting toilets and separated urine collectors are used, to produce fertilizer for local food crops. Helophytic filtration systems enable on-site, gray-water recycling, whilst waste heat from the houseboats is captured and reused. Thus, the site is ecologically regenerated, resources are looped and a temporary home for businesses adopting the circular development model is provided.

\subsection{Paris}

Paris has also adopted a city-regional approach to looping construction materials, food and water. It has taken a similar approach to Amsterdam in facilitating circular construction, through the provision of material flow data, online marketplaces and resource banks. It has been particularly successful in dealing with the soil excavated from construction sites (using the sol-dating app).

Paris aims to create a local circular food system through the reuse of food waste and the regional production of food, both in the city and in surrounding districts. This isencouraged by the Parisculteurs initiative, whichaims to cover the city's roofs and walls with 100 hectares of vegetation by 2020 . One third of this space will be dedicated to urban farming. There is a stronger "solidarity" narrative in Paris suggesting that feeding the urban poor is a priority, when compared to Amsterdam. Food reuse is also legally enforced. Examples of food-reuse schemes include public service contracts with food markets; food reuse cafes (e.g., Freegan Pony) and community fridges (les Frigos Solidaires). Any food which cannot be reused in the city is converted into biogas and supplements the local energy supply.

Paris also has a gray-water recycling system, which has existed for two centuries. Most of the graywater $(98 \%)$ is consumed by the municipality to maintain public infrastructure. The graywater is very inexpensive and used in large quantities. However, the city is considering replacing the existing gray infrastructural system with a blue-green alternative. This could help to reduce water consumption and regulate pollution and urban temperatures, enabling the city to adapt to climate change.

Paris also co-ordinates the strategic, adaptive reuse of sites and buildings through initiatives such as Paris Reinvented and Paris Culteurs. Paris Reinvented is an initiative which has formalized the process of the strategic adaptive reuse of sites and buildings in Paris since 2014. Temporary planning permissions, space brokers and online marketplaces help to facilitate tactical urbanism, which has precipitated many pop-up activities in the capital, including urban farming. A variety of projects have emerged, including: Les Grands Voisins, Freegan Pony, Friche Miko and Jardin d'Alice. Les Grands Voisins-a pop-up social enterprise - was particularly successful, providing a homeless hostel, workshop for artisans, pop-up shops and start-ups, allotments and recreational facilities.

\subsection{London}

London also provides examples of circular systems of provision. The Queen Elizabeth Olympic Park (QEOP), is a new eco-district, built for the 2012 London Olympics, which has integrated three circular actions into its construction and operational processes. The QEOP is the largest urban park to have been created in Europe over the last 150 years. It is undergoing a process of ecological restoration to create a healthy urban ecosystem. Bioremediation, local clean-up programs and conservation schemes have helped to ecologically regenerate this previously industrial area. Residents live within $300 \mathrm{~m}$ of at least two hectares of green space. Diverse, natural species have been planted across the park. Waterways have been improved, whilst sustainable urban drainage systems have been fully integrated into the public realm. 
Circular construction systems (e.g., soil-washing, materials exchange platforms, resource banks) have limited material waste from the site and adaptive infrastructure integrated into the Olympic development, which was repurposed post-games. For example, nine modular cabins that formed the 'High Street' in the Athletes' Village are now used as a community hub in Hackney Wick. QEOP provides an example of how, by designing for adaptability from the outset, buildings, products and materials continue to provide high value return beyond their initial purpose. An Asset Disposal scheme was introduced in QEOP to help contractors re-use items and materials after the Olympic Games by selling them or gifting them to charities and good causes.

In contrast, Brixton provides an example of tactical circular urbanism in an existing urban neighborhood. Brixton is a transition town with twin aims to tackle climate change and resource consumption. A series of sustainable community-led schemes, integral to circular development, have emerged in the neighborhood (e.g., Pop-up Brixton, Brixton Café, Loughborough Farm and the Remakery). These were facilitated by the release of municipally owned sites and granting of temporary planning permissions/leases. Local food reuse (e.g., Brixton Café) and urban farming schemes (e.g., Loughborough Junction Farm), supported by the local currency (Brixton Pound), have been established which help to reinforce a circular food system. The Remakery provides a space in which the community can learn to repair or recycle unwanted or broken goods and materials. Pop Brixton provides employment opportunities for local people in the pop-up economy.

\subsection{Stockholm}

In Stockholm, circular thinking has been embedded into development decisions for 25 years. Circular principles first manifested in Stockholm (as Ecocycles I.0) in Hammarby. The district developed the infrastructure required to create a closed-loop, waste-to-energy system. The system utilized the existing city-wide infrastructural systems (district heating system; the Högdalen combined heat and power plant and the Hammarby thermal power station) together with new technologies for converting sludge into fertilizer and biogas. The heat produced from the process of purifying wastewater is used by the thermal power station. The biogas is used for cooking and to power the public transport system. Refuse is burnt to provide heating for homes and businesses. Thus, sewage, waste-heat and refuse are used to produce energy.

More recently, circular development has manifested in Stockholm Royal Seaport [69]. Here, Ecocycles 1.0 was modified to encompass resource cycles from both the living and port environments (Ecocycles 2.0). Organic waste produced on ships and from the maintenance of green spaces in the seaport are also used to feed the waste-to-energy system. It is also used to produce compost, which can substitute for fertilizers made with petrochemicals.

A gray-water reuse system has been added to Ecocycles 2.0. The system stores stormwater in retention ponds or caverns, which limits flash-flooding in SRSP. The system reduces the damage to the aquatic environment caused by the release of wastewater into the harbor. The stored water can be reused for watering vegetation in the port. The green-blue infrastructure protects gray infrastructure in the port. Finally, bioremediation has been used to restore soil, caverns and waterways.

\section{City Analysis}

The sustainability benefits of adopting circular systems in these cities were investigated through interviews with key stakeholders (Table 5). This section presents the broad findings of those interviews and where possible supports these findings with examples, quotes and extracts from the gray literature. 
Table 5. Benefits of circular systems identified by service and infrastructure providers.

\begin{tabular}{|c|c|c|c|c|c|c|c|c|}
\hline \multirow[t]{2}{*}{ Circular Systems } & \multirow[t]{2}{*}{ City } & \multirow[t]{2}{*}{ Scale } & \multirow[t]{2}{*}{ Loop } & \multirow[t]{2}{*}{ Adapt } & \multirow[t]{2}{*}{$\begin{array}{l}\text { Ecologically } \\
\text { Regenerate }\end{array}$} & \multicolumn{3}{|l|}{ Benefits Indicated by Interviews } \\
\hline & & & & & & Ecological & Social & Economic \\
\hline $\begin{array}{l}\text { Circular } \\
\text { Construction }\end{array}$ & $\begin{array}{l}\text { Amsterdam } \\
\text { London } \\
\text { Paris }\end{array}$ & $\begin{array}{l}\text { City-region } \\
\text { Neighborhood } \\
\text { (QEOP) } \\
\text { City-region }\end{array}$ & $\boldsymbol{v}$ & $\checkmark$ & & $\begin{array}{l}\text { Reduce material consumption; } \\
\text { reduce GHG emissions }\end{array}$ & $\begin{array}{l}\text { Reuse of structures for } \\
\text { community projects }\end{array}$ & $\begin{array}{l}\text { Creates economic value; } \\
\text { localized value chain; } \\
\text { creates jobs; avoids landfill } \\
\text { costs. }\end{array}$ \\
\hline $\begin{array}{l}\text { Circular Food } \\
\text { System }\end{array}$ & $\begin{array}{l}\text { Paris } \\
\text { London }\end{array}$ & $\begin{array}{l}\text { City-region } \\
\text { Neighborhood } \\
\text { (Brixton) }\end{array}$ & $\boldsymbol{v}$ & $\checkmark$ & $\checkmark$ & $\begin{array}{l}\text { Reduce food waste; } \\
\text { reduce GHG emissions; } \\
\text { increases resource sufficiency; } \\
\text { restores ecosystem services, } \\
\text { increase in environmental } \\
\text { awareness }\end{array}$ & $\begin{array}{l}\text { Empowers communities; } \\
\text { opportunities to socialize; } \\
\text { offers access to affordable } \\
\text { food for low income } \\
\text { groups; builds new skills in } \\
\text { the community; increases } \\
\text { community resilience }\end{array}$ & $\begin{array}{l}\text { Creates economic value; } \\
\text { localized value chain; } \\
\text { creates jobs; activates } \\
\text { vacant and unused spaces; } \\
\text { avoids landfill costs }\end{array}$ \\
\hline $\begin{array}{l}\text { Adaptive Reuse of } \\
\text { Spaces/Infrastructure }\end{array}$ & $\begin{array}{l}\text { Amsterdam } \\
\text { Paris } \\
\text { London }\end{array}$ & $\begin{array}{l}\text { Neighborhood (De } \\
\text { Ceuvel) } \\
\text { City-region } \\
\text { Neighborhood } \\
\text { (QEOP \& Brixton) }\end{array}$ & $\boldsymbol{v}$ & $\checkmark$ & $\checkmark$ & $\begin{array}{l}\text { Reduce material and land } \\
\text { consumption; reduce GHG } \\
\text { emissions; restores ecosystem } \\
\text { services; increases resource } \\
\text { sufficiency; provides cultural } \\
\text { services; }\end{array}$ & $\begin{array}{l}\text { Stabilizes existing } \\
\text { communities; increases } \\
\text { community resilience; } \\
\text { builds local symbiotic } \\
\text { capital; builds new skills in } \\
\text { the community; access to } \\
\text { affordable accommodation; } \\
\text { provides affordable } \\
\text { accommodation }\end{array}$ & $\begin{array}{l}\text { Reduces accommodation } \\
\text { costs; creates economic } \\
\text { value; localized value } \\
\text { chain; creates jobs; } \\
\text { activates vacant and } \\
\text { unused spaces; increases } \\
\text { value of property and land }\end{array}$ \\
\hline $\begin{array}{l}\text { Water and Nutrient } \\
\text { Recycling }\end{array}$ & $\begin{array}{l}\text { Amsterdam } \\
\text { Paris } \\
\text { Stockholm }\end{array}$ & $\begin{array}{l}\text { City-region } \\
\text { \& Neighborhood } \\
\text { (De Ceuvel) } \\
\text { City-region } \\
\text { Neighborhood } \\
\text { (Hammarby } \\
\text { \&SRSP) }\end{array}$ & $\boldsymbol{v}$ & $\checkmark$ & $\checkmark$ & $\begin{array}{l}\text { Reduce potable water } \\
\text { consumption; reduce GHG } \\
\text { emissions; increases resource } \\
\text { sufficiency; restore ecosystem } \\
\text { services; increase in } \\
\text { environmental awareness, } \\
\text { increases resilience to climate } \\
\text { change; increase food security }\end{array}$ & & $\begin{array}{l}\text { Creates economic value; } \\
\text { localized value chain; } \\
\text { creates jobs; reduces cost of } \\
\text { water purification for } \\
\text { non-drinking uses, } \\
\text { increases value of property } \\
\text { and land, avoids costs of } \\
\text { grey infrastructure to } \\
\text { present flooding. }\end{array}$ \\
\hline $\begin{array}{l}\text { Waste Heat } \\
\text { Recovery }\end{array}$ & $\begin{array}{l}\text { Amsterdam } \\
\text { Stockholm }\end{array}$ & $\begin{array}{l}\text { Neighborhood (De } \\
\text { Ceuvel) } \\
\text { Neighborhood } \\
\text { (Hammarby } \\
\text { \&SRSP) }\end{array}$ & $\checkmark$ & & & $\begin{array}{l}\text { Reduce fossil fuel } \\
\text { consumption; } \\
\text { reduce GHG emissions; } \\
\text { increase in environmental } \\
\text { awareness }\end{array}$ & Provides affordable heat & Reduces energy costs \\
\hline
\end{tabular}


Table 5. Cont

\begin{tabular}{|c|c|c|c|c|c|c|c|c|}
\hline \multirow[t]{2}{*}{ Circular Systems } & \multirow[t]{2}{*}{ City } & \multirow[t]{2}{*}{ Scale } & \multirow[t]{2}{*}{ Loop } & \multirow[t]{2}{*}{ Adapt } & \multirow[t]{2}{*}{$\begin{array}{l}\text { Ecologically } \\
\text { Regenerate }\end{array}$} & \multicolumn{3}{|l|}{ Benefits Indicated by Interviews } \\
\hline & & & & & & Ecological & Social & Economic \\
\hline Waste to Energy & Stockholm & $\begin{array}{l}\text { Neighborhood } \\
\text { (Hammarby } \\
\text { \&SRSP) }\end{array}$ & $\boldsymbol{v}$ & & & $\begin{array}{l}\text { Reduce fossil fuel } \\
\text { consumption; } \\
\text { reduce GHG emissions; } \\
\text { increase resource sufficiency }\end{array}$ & & $\begin{array}{l}\text { Creates economic value; } \\
\text { localized value chain; } \\
\text { creates jobs. }\end{array}$ \\
\hline $\begin{array}{l}\text { Ecological } \\
\text { Restoration }\end{array}$ & $\begin{array}{l}\text { London } \\
\text { Stockholm } \\
\text { Amsterdam }\end{array}$ & $\begin{array}{l}\text { Neighborhood } \\
\text { (QEOP) } \\
\text { Neighborhood } \\
\text { (SRSP) } \\
\text { Neighborhood (De } \\
\text { Ceuvel) }\end{array}$ & $\checkmark$ & $\boldsymbol{v}$ & $\boldsymbol{v}$ & $\begin{array}{l}\text { Reduce land consumption } \\
\text { outside the city; restore } \\
\text { ecosystem services; increase in } \\
\text { environmental awareness; } \\
\text { reduces GHG emissions; } \\
\text { increases resilience to climate } \\
\text { change }\end{array}$ & $\begin{array}{l}\text { Health benefits; } \\
\text { opportunities to socialize } \\
\text { and for recreation. }\end{array}$ & $\begin{array}{l}\text { Activates vacant \& unused } \\
\text { spaces; increases value of } \\
\text { property \& land; avoids } \\
\text { costs of grey infrastructure } \\
\text { to prevent flooding; avoids } \\
\text { health costs; avoids } \\
\text { chemical remediation costs }\end{array}$ \\
\hline Reuse of Goods & London & $\begin{array}{l}\text { Neighborhood } \\
\text { (Brixton) }\end{array}$ & $\checkmark$ & & & $\begin{array}{l}\text { Reduce material consumption } \\
\text { and waste; reduce greenhouse } \\
\text { gas emissions. }\end{array}$ & $\begin{array}{l}\text { Empowers communities; } \\
\text { opportunities to socialize; } \\
\text { access to affordable goods } \\
\text { for low income groups; } \\
\text { builds new skills in the } \\
\text { community }\end{array}$ & $\begin{array}{l}\text { Creates economic value; } \\
\text { localized value chain; } \\
\text { creates jobs; avoids landfill } \\
\text { costs }\end{array}$ \\
\hline
\end{tabular}




\subsection{Ecological Benefits}

All the interviews confirmed that looping (e.g., circular construction, circular food systems, water and nutrient recycling) and adaptive actions (adaptive reuse of buildings and sites) reduce the consumption of resources. In Amsterdam, it is estimated that the high-value reuse and recycling of construction waste saved 500,000 tonnes of materials per annum [70]. In the Queen Elizabeth Olympic Park (London), soil-washing operations resulted in $80 \%$ of excavated soil being reused on site [71]. In Paris, the sol-dating platform (which facilitates soil exchanges between sites) recovered more than $30,000 \mathrm{~m}^{3}$ of soil in the Île-de-France region, producing a 50\% reduction in inert soil management costs [72].

Unfortunately, increased resource efficiencies may also result in a rebound effect. The interviews in Stockholm and Paris highlighted this problem with the ecocycles and graywater reuse systems [73,74]. In Hammarby, ecocycles reduced fossil fuel consumption by 28$42 \%$, water consumption by $41-46 \%$ and waste going to landfill by $90 \%$ [75]. This produced cost savings for households, which enabled them to increase their overall consumption of energy $[74,76]$.

We found in Hammarby, resource savings were lower than expected. We thought this resulted from a lack of understanding of how to use the system effectively amongst residents. However, we later found that the rebound effect was largely responsible. The savings made by the system, reduced the cost of energy for the consumer, and so residents increased the overall quantity of energy they consumed. [74]

Similarly in Paris, the gray-water reuse system has reduced the quantity of potable water consumed. However, the low cost of gray-water, has led to over-consumption [73]. The city is considering replacing the gray-water system and charging for all water consumed, in response to this rebound effect.

The interviewees also mentioned that looping could increase urban resource security $[73,74,77-83]$. For example, the Paris strategic plan encourages land designation for urban agriculture throughout the region [84].

Increasing local food security provided the rationale for creating a local circular food system in Paris. [73]

In Stockholm, ecocycles were introduced to reduce Stockholm's reliance on fossil fuels, making it more energy secure [85]. Amsterdam is also attempting to increase food security. The power-to-protein project (which extracts ammonia from sewage to create high value proteins) could provide Amsterdam 's population with $35 \%$ of their primary protein requirement [86]. The scheme will also reduce land and water needed to grow feedstock crops, as well as reduce energy consumed in the production and transportation of feedstock [87].

Interviews $[77,78,88]$ in Amsterdam suggest that looping construction and organic waste can reduce greenhouse gas emissions.

Circular systems are fundamental to achieving a reduction in greenhouse gas emissions

here in Amsterdam. They may also help us to adapt to climate change by increasing resource security". [78]

This is supported by the findings from the circle scan project. It calculated high value recycling and reuse of construction waste could save 75,000 tonnes of $\mathrm{CO}_{2}$ per annum, whilst the dismantling and separation of components and materials from buildings could save 100,000 tonnes of $\mathrm{CO}_{2}$ per annum [70]. The circle scan project calculated that cascading of organic waste flows (300,000 tonnes of $\mathrm{CO}_{2}$ per annum), organic waste separation (100,000 tonnes of $\mathrm{CO}_{2}$ per annum), recovering nutrients from organic waste (100,000 tonnes of $\mathrm{CO}_{2}$ per annum), and the establishment of a bio-refinery hub $(300,000$ tonnes of $\mathrm{CO}_{2}$ per annum) could save 800,000 tonnes of $\mathrm{CO}_{2}$ per annum in Amsterdam [70]. Equally, energy recovery from organic waste helps decarbonize the local energy supply. For example, waste biomass is used to produce biogas in Paris, which is injected into the 
heating system to decarbonize it [73]. In Stockholm, ecocycles have reduced $\mathrm{CO}_{2}$ emissions by as much as $29-30 \%$ [75].

The importance of ecological regeneration in restoring ecosystem services was reported in several interviews [73,77,78,89-91]. In De Ceuvel site, bioremediation and above ground services were critical to the project's success. In the longer-term, bioremediation will enable the site to be used for commercial activities [78]. This raises the value of the land. De Ceuvel indicates a potential mechanism for the remediation of contaminated, post-industrial sites, as part of a wider tactical urbanism strategy. Bioremediation was also successfully used in the Queen Elizabeth Olympic Park (QEOP) and Stockholm Royal Seaport (SRSP) to treat contaminated ground water and caverns (now used as garages).

Blue-green infrastructure was integrated across the QEOP and SRSP sites. This increased biodiversity, created green corridors for active transport and aided soil formation $[90,92]$. It also regulated local hydrology, to address both drought and flooding conditions for the QEOP site [90]. In SRSP, a mixture of permeable surfaces and retention ponds were used to prevent flash-flooding and enable watering vegetation and reducing pollution in adjacent waterways [74,91].

The ecological regeneration of the port system in the Royal Seaport helps to support natural cycles. This in turn helps with local water management, both flash flooding and pollution. [91]

For both sites, the integration of blue-green infrastructure into the built environment was also seen as a solution for adapting to climate change, particularly in terms of water management. In Paris, the replacement of gray with blue-green infrastructure as a means for rainwater capture and gray-water recycling, was also seen as a climate adaptive response [73].

De Ceuvel and Brixton provided evidence that community engagement in circular projects would increase environmental awareness [74,93]. De Ceuvel is a circular living lab. It has materialized the principles of circular development and made them sharable. According to the interviews $[78,89]$, a co-design process involving De Ceuvel's inhabitants and circular designers, was fundamental to its success. It helped to raise inhabitants' awareness of circular resource flows, the systems needed to facilitate them and benefits of adoption [89]. This approach enabled residents to adopt circular practices quickly. De Ceuvel's residents identified strongly with their neighborhood and were proud of its ecological achievements [89]. This helped to further reinforce circular practices.

A similar (albeit less powerful) dynamic was reported by Brixton's Transition Towns team [92]. The various local projects (e.g., community food and energy production, repair workshops, pop-up enterprises) combined with a local currency, were badged as actions to combat climate change. These helped the community to become more aware of how and where resources were produced [92]. Community engagement in the projects helped develop the expertise and skills needed to adopt circular practices [92-95]. The creation of local jobs (attached to the projects) reinforced local support for the schemes [79,92,93,96-98]. Thus, environmental awareness has grown in the community, alongside circular practices and support for these schemes.

Awareness of climate change and resource consumption has grown amongst the local population over the period of several years. This is as a result of people's engagement in the local projects, and also their local visibility. However, environmental awareness for many has grown because of the projects offering other social and economic benefits, and not because of an initial interest in the environment. [92]

\subsection{Social Benefits}

The interviews identified a number of social benefits derived from circular development.

In Paris, we see social solidarity as the key goal for the circular strategy. It is essential we use circular strategies to provide better access to resources for those most in need". [73] 
Looping actions can provide more affordable resources (e.g., heat, accommodation, goods and food) for low-income groups $[73,79,82,92,95,98]$. This was exemplified by the food reuse schemes (e.g., Brixton café, Freegan Pony and Les Frigos Solidaires) and repair cafés (e.g., remakery in Brixton and recycleries in Paris) in Paris and London $[73,92,95,96]$. De Ceuvel and Hammarby also demonstrated how waste heat could be captured and reused, reducing the costs of heating $[83,89]$. However, neither explicitly benefitted low income groups.

Circular actions which engage communities, offer opportunities for people to socialise, gain new skills and earn money [73,79-82,90,92,93,95-98]. Thus, they can help to build local social, economic and human capital. Transition Towns Brixton actively encouraged the creation of these capitals through its support of various social enterprises and a local currency.

The intention (in Brixton) was to create a stronger, more skilled, resource secure community, which was more resilient and thus able to address climate change. [92]

The interviews indicate that these projects have strengthened local symbiotic capital $[79,81,92,93,95-97]$. They also provide an arena in which the local people can test different social practices, which offer ecological, social and economic opportunities.

The interviews [96-98] highlighted that the adaptive reuse of space in Paris and London, for a variety of pop-up activities (some circular activities) built local social, economic and human capital. Temporary planning permissions and leases offered affordable spaces for lower value activities for a short period $[92,97,98]$. The Brixton cluster of projects and Parisien pop-up projects (Reinvented, Paris Culteurs, Leas Grands Voisins) demonstrated how these activities helped to empower and stabilize local communities [92,98]. They revitalized areas culturally and economically. This resulted in greater investor interest and increasing land values. Unfortunately, this also meant the eventual loss of many social enterprises [92,96-98]. These cases highlight a significant problem with securing the longevity, or scaling-up circular projects, particularly if they have a social solidarity focus.

The health benefits of ecological regeneration were highlighted by interviews [74,90,91]. In Stockholm Royal Seaport and Queen Elizabeth Olympic park, the population had excellent access to blue-green infrastructure. The neighborhoods were well connected to the city via blue-green active transport corridors. The development agencies believed this would be beneficial for residents' health, although it has not been monitored [90,91].

It is expected that the inclusion of green infrastructure throughout the site will offer health benefits to those living in and around the park (Queen Elizabeth Olympic Park., Due to it's sheer size, health benefits are also expected for the rest of Greater London. However, there is an issue about how to measure this effectively. If we could measure all the benefits offered by the park, it might help to preserve it long-term. This will be more important as pressure builds to develop it. [90]

However, in both instances, those benefitting from the ecological regeneration of the urban system, were affluent households. Property prices and rental costs in both urban districts were extremely high. Interviewees [90,91] suggested that a process of green gentrification had effectively excluded low-income groups from both neighborhoods.

\subsection{Economic Benefits}

The interviews highlighted that looping, adaptive and regenerative actions could help service providers, insurance companies, residents and local authorities avoid costs $[73,74$, $77,78,88-90,98,99]$. For example, the reuse of buildings or waste heat will avoid construction or heating costs [89]. The reduction of construction and organic waste will reduce the cost of landfill $[73,77,88,99]$. Increase in the use of green infrastructure will help to reduce the cost of gray infrastructure to prevent flooding and the cost of insuring properties in the flood-prone zones $[74,90,91]$. The integration of blue-green infrastructure into the urban fabric could also help to avoid health costs $[73,74,90,91]$. However, these avoided costs need to be estimated to make a stronger case for circular systems. 
The majority of service providers interviewed suggested that economic value and jobs would be created by adopting looping actions in cities. Circular construction $[73,77,88,90,99,100]$, circular food systems [73,79-82], the looping of organic waste, nutrients and water [88], will all create local economic value and generate employment opportunities. However, there is limited data (particularly at a city-level) to support this assumption. Projections have been made for London that a circular economy could create 12,000 new jobs by 2030, of which 5\% would be in the construction industry [101]. Circular construction could generate an economic value of between GBP 3 bn and GBP 5 bn annually by 2036 [102]. The capital's circular food economy could add GBP 2-4billion annually to GDP by 2036 (ibid). Similar projections have been made for Amsterdam. Estimates suggest that circular construction could produce EUR 85,000,000 annually and 700 jobs; meanwhile, the organic waste (including food waste) sector is expected to generate EUR 140,000,000 annually and create 1250 jobs (ibid).

Monitoring is needed to determine the actual impact on the economy and jobs created. The OECD suggested that the economic value and number of jobs created by a circular economy may have been over-estimated. This requires more research at a city-level. It is also unclear what jobs might be displaced by a shift towards circular actions. It is uncertain whether the jobs created would be secure and well paid. For example, circular social enterprises in Brixton relied on volunteers, donations and access to cheap space [92,96]. These activities were neither well paid nor secure. There is no data to identify who benefits from the circular employment opportunities generated. It has been suggested that a wide range of jobs requiring a diversity of skills is likely to be emerge from the circular, pop-up and bio-economies. However, the accessibility of these jobs to the socially excluded requires further investigation.

It is important to ensure that everyone can access good employment opportunities generated by the circular strategy (in Paris). This will require the introduction of skills development programs. [73]

The interviews $[73,78,89,90,92,96,98]$ reinforced the findings in the literature that the reuse of vacant and unused spaces in cities results in economic revitalization and boosts local real estate value. In the early stages, these circular activities tend to be social enterprises (e.g., Brixton Café, Remakery, Les Grands Voisins). But the cases demonstrate the insecurity of social enterprises. If these pop-up, social enterprises are not sustained, as they are replaced with commercially successful enterprises [79,92,97-99]. Thus, the knowledge, human and social capital generated by the projects, which could set urban systems onto new sustainable development trajectories, is lost [79,92,97].

The problem with the approach taken here in Brixton, is that these innovative projects can't be sustained long-term. They rely too heavily on good will, volunteers, donations and temporary spaces. If we value them, then local government will need to protect them and help them to succeed. Otherwise all the valuable benefits and capital generated by the projects are lost. [92]

Furthermore, the interviews suggested that low income groups are unlikely to benefit from the ecological regeneration of neighborhoods $[90,100]$. In both QEOP and SRSP, a lack of affordable housing and relocation of some existing low-income residents to new neighborhoods had resulted from the green gentrification process. Interviewees suggested that poorer groups were less likely to benefit from the rising land and property values in these districts $[90-92,96]$. Thus, an important question to answer is who benefits from the economic outcomes of circular development.

\subsection{Synergistic Benefits}

The case studies provide some evidence (originating from the interviews and technical reports indicated in the text below and Figure 3) that the three circular actions can work synergistically together to reinforce or amplify the benefits of circular development. For instance, looping actions help to regenerate urban ecosystems. Recycling soil, organic waste, 
gray and wastewater removes pollutants and regenerates the local ecosystem. In SRSP, rainwater storage and graywater recycling reduced localized flooding and the dispersal of pollutants into the harbor, which helped to restore the marine environment [74,91]. In QEOP, the soil recycling schemes improved soil quality and enabled the successful planting of vegetation in the park. This helped to reduce air pollution, reduce surface run-off and enable local carbon sequestration $[90,100]$. Energy recovery from organic waste (as operated in Paris) or heat capture (as used in de Ceuvel) reduce greenhouse gas emissions [73,89]. The recycling of residual nutrients to provide food protein (as in Amsterdam) reduces the land needed to grow food and the emissions from transportation, which helps to restore ecosystems $[78,88]$.

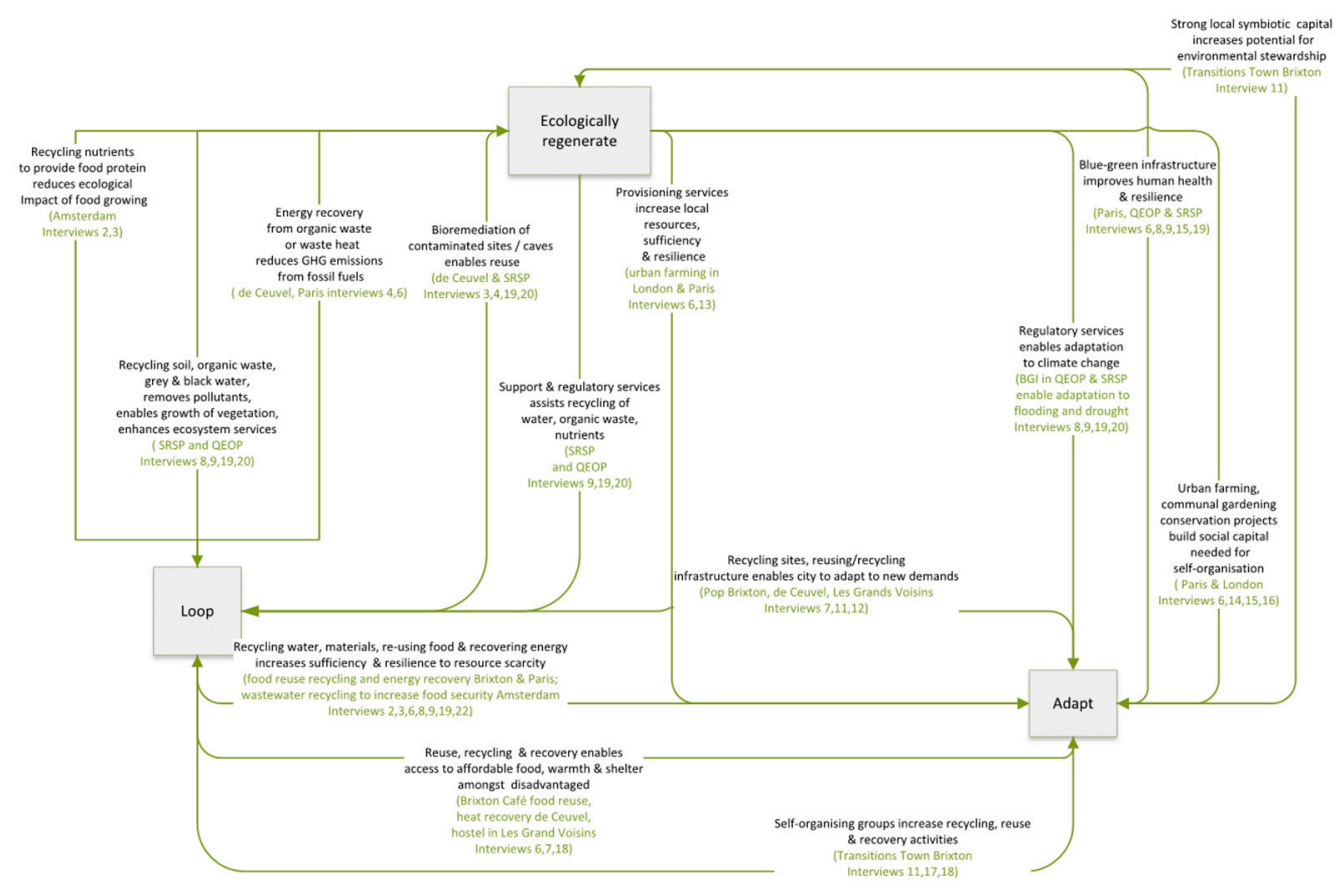

Figure 3. Synergistic benefits from adopting a circular development pathway (Source: Author's own).

The regeneration of the urban ecosystem may also boost support and regulatory ecosystems services, which enhance the natural loops for water, organic waste and nutrients. The provision of blue-green infrastructure (BGI) moderates water flow and storage; it limits overspill from sewers and thus reduces the contamination of the potable water supply, an approach adopted in QEOP [100]. BGI also produces organic waste, which can be composted and used to improve local soil quality (as seen in SRSP). It also reduces the greenhouse gas emissions associated with fertilizers and burying organic waste [74,91]. Bioremediation increases the potential for the reuse of contaminated sites in cities. Phytoremediation enabled the contaminated site in De Ceuvel to be reused for commercial and leisure activities [78,89]. The microbial remediation of naphtha in caves in SRSP enabled their reuse for storm-water storage, which was then used to water vegetation locally [74,91].

Ecologically regenerative actions also increase the adaptiveness and resilience of urban ecosystems. Healthy urban ecosystems support the production of resources, which increases urban resource security. The clearest example of this is urban farming. Both in London and Paris, urban farming is seen as part of the solution for increasing local food security $[73,80]$. Local food production increases access to fresh food and thus can improve human health [79-81]. More broadly, the integration of BGI into cities will improve the health of the population and increase urban resilience to pandemics. Interviewees in SRSP, Paris and QEOP all highlighted the link between a healthy ecosystem, a healthy population and urban resilience $[73,80,91,100]$. BGI also helps to regulate local climate and water 
cycles, which enables urban systems to adapt to climate change. This was a key motivation for introducing BGI into the SRSP and QEOP developments [74,90,91,100].

Looping actions can also help increase the adaptiveness of urban ecosystems, which helps to build urban resilience. Recycling sites and infrastructure enables the city to adapt. The use of temporary planning permissions and leases allow cities to react quickly to rapid changes in the landscape, like economic and health crises [97,98]. This process provides temporary sites for pop-up circular activities, as seen in London and Paris [92,97,98]. It also provides space for activities which reflect local needs, for example by providing a hostel and allotments in Les Grands Voisins [98]. This flexibility in the way in which space is used in cities increases urban resilience.

Recycling water, re-using food and recovering energy can all help increase local sufficiency and resilience to resource scarcity. Black-water recycling in QEOP was introduced to decrease problems of drought in the area. This is a problem that is expected to get worse with climate change $[90,98]$. In Paris, the re-use of food is part of the capital's food security strategy [73]. In Stockholm energy recovery from residual materials and heat reduces reliance on fossil fuels. Thus, the city is more energy secure [83,91].

Looping actions also increase urban resilience by making affordable resources available to low-income groups. This is particularly important when there are rapid economic changes, and the proportion of low-income groups in the population expands. For example, repair cafes and food reuse schemes in Paris and London have increased access to affordable food and goods amongst the urban poor $[73,82,95]$. The temporary reuse of buildings to provide affordable shelter was also highlighted [73]. The capture of waste-heat from buildings (as in de Ceuvel) or from cleansing of wastewater (as in Stockholm) could also potentially offer affordable heating for low income households [83,89].

Public engagement in all circular activities (both looping and regenerative) helps to build local human, social, physical and economic capital (i.e., local symbiotic capital). This increases community adaptiveness and resilience [73,79-81]. It is best demonstrated by the Brixton case. Here, local expertise has developed in growing food, generating renewable energy, repairing old goods and reusing vacant spaces. The infrastructure and spaces needed to support these activities have emerged. Some economic capital has been generated and social networks have been strengthened in this process [81,92,93,95-97]. The generation of these local capitals provide the infrastructure needed for the community to remain agile and resilient to external pressures. It also provides the resources to enable environmental stewardship [92]. Thus, the evidence suggests the need to take a more holistic approach to circular development, to profit from the synergistic benefits which are indicated. However, these findings rely largely on anecdotal evidence. It is important that the synergistic benefits of circular development are monitored if a strong case is to be made for its adoption.

\section{Discussion}

The results from the case studies validated the benefits framework, produced from the inductive content analysis of the literature. The research demonstrates the ecological, economic and social benefits of adopting circular actions and circular systems in cities. It also highlights the importance of applying all three circular actions in a development strategy, to maximise benefits from the synergies created. These findings provide an evidence-base for urban policymakers when considering circular development as a strategy for urban development. However, more data needs to be collected, which measures the impact and monitors the benefits of circular development, to further support the case.

The research does suggest that the benefits produced by different circular systems are likely to advantage different groups in society. For example, circular construction largely benefits developers and construction companies. Food reuse benefits the urban poor and local authorities who would otherwise need to deal with the food waste. Of course, this may alter with new regulatory frameworks. If dumping food waste is illegal (as in Paris), then those generating the waste stand to benefit the most from reuse systems (i.e., all the 
producers of waste). Currently, it is easier to determine who benefits directly from circular systems than determine the scale of benefits which accrue.

The research also suggests that timing may affect the benefits of circular actions taken in cities. For example, the benefits of ecological regeneration will take longer to present than those accruing from the adaptive reuse of buildings. Equally, those initial benefits may produce new problems over time. This is the case with green gentrification. Thus, the point at which benefits are measured almost certainly matters.

The findings from the case studies provide policymakers with more information about the benefits of specific circular systems (e.g., circular construction and circular food systems). The benefits emerging from implementing circular systems are similar across the cities studied. The corroboration between cases strengthens the findings for each system. Thus, benefits of circular food systems are likely to be the same across similar, relatively prosperous, western European cities. However, we might expect to see a different set of outcomes if we compared these cases with cities in the developing world or cities at different stages of economic development. We may also find different circular systems in different contexts, or at least variations in the way they are implemented.

The case studies and the inductive content analysis of the literature also highlight several shortcomings of circular development. The first relates to the rebound effect identified in the literature [33]. Resource efficient, looping systems reduce the cost of the resource to the producer (and eventually the consumer), which encourages an overall increase in direct (or indirect) resource consumption. This rebound effect is illustrated by the Paris gray-water recycling system [73] and Stockholm Ecocycles [74,76,91,103]. In both instances, the low cost of resources (energy and graywater) resulted in higher levels of consumption. The rebound effect may be addressed through resource pricing (as is being considered for Paris) or consumer education (as was the case in Hammarby Stockholm). Regardless, these experiences highlight the need to also examine the unintended consequences of adopting a circular development path in cities.

The second shortcoming which emerged from the research was the problem of evaluating sustainability benefits. This was discussed in the literature and pivots on the need to internalize ecological and social externalities into the economic evaluation of development decisions. The case studies demonstrated how ecosystem services are under-valued. Yet the health and security of the urban ecosystem is threatened if these services are undermined. Interviewees pressed the need to value ecosystem services to avoid unnecessary health, insurance, gray-infrastructure and climate adaptation costs $[73,74,78,89-91,98,103]$, as well as to protect space for ecologically regenerative systems in cities $[70,73,74,90,100]$.

The case studies also demonstrated that the social benefits emerging from circular social enterprises were under-valued. Thus, social enterprises were often underresourced $[79,81,92,93,95]$. The benefits to society offered by these social enterprises, in terms of developing people's skills, strengthening communities and enabling access to resources for low-income groups, were demonstrably under-valued. Thus, social circular enterprises seem unable to compete with commercial alternatives, particularly in cities where land values were high $[92,97,98]$. New approaches to valuing these societal benefits are needed, in order for societal goods to be given equal weight in development decisions. A more holistic approach to evaluation would ensure those making development decisions were better informed.

Finally, the literature suggested that the benefits of adopting a circular development approach were not spread equally across society $[47,54,55]$. Both SRSP and QEOP cases support this notion. In both cases, circular development resulted in green gentrification, rising land values and loss of low-income groups from both areas $[90,98,103]$. Therefore, low-income groups did not benefit from access to green space and adjacent ecosystem services provided by circular development. Yet the health benefits of locally accessible green space are greatest for these groups, because they tend to remain in their local area.

Circular solidarity activities particularly benefit the urban poor (e.g., food reuse schemes, community farming or energy, repair cafes, temporary affordable accommoda- 
tion). However, the case studies show these projects are more likely to fail because they rely on donations, volunteers or are accommodated in spaces with temporary leases [92,96,97]. This lack of commercially viability means solidarity projects are less competitive, yet they are important for the wellbeing of low-income groups [73].

Circular development also has the potential to provide a variety of sustainable job opportunities, for a range of skills sets. However, it is more likely that low-income and poorly educated groups will be employed in activities which are low paid, insecure or hazardous. It is important that these potential inequalities are addressed if circular development is to benefit those most in need.

\section{Conclusions}

In conclusion, the research contributes to the urban sustainability and circular cities literature by providing an analysis of the sustainability benefits of circular development. The findings suggest that circular development could address many of the ecological, social and economic problems currently facing cities. It supplies some evidence of the synergistic benefits created through combining the three circular actions in cities. It also identifies the potential benefits of adopting select circular urban systems. Thus, taking a circular approach to development could help to reinvigorate our cities and is likely to be worth investing in.

However, there are limitations in this research, particularly around the reliability of the benefits framework and synergistic benefits. Both could be directly tested with a larger group of key stakeholders to increase their reliability. A limited amount of data has been collected to quantify the benefits which accrue from circular development. Some data identifying reduction in resource consumption, greenhouse gas emissions, jobs and income created by circular construction, circular organic waste and circular food systems has been collected. The data monitoring many of the socio-ecological benefits of circular development is lacking. Thus, it is hard to identify the scale of the benefits which accrue from adopting a circular development approach. Thus, more quantitative data is needed to test the framework and synergistic benefits.

In addition, investigations into cities operating across different contexts (i.e., in different geographical regions or with different economic profiles) are needed to explore the variety of possible circular urban systems and the benefits which may accrue from adopting them. More research focused on the costs of circular development, the unintended consequences and the unequal distribution of benefits across society is also needed. More monitoring to determine who is affected by circular development and the scale of the benefits which accrue is additionally required. This information could help policymakers to ensure that circular development is implemented in an equitable and socially-just fashion.

Funding: Funding was provided by the Grand Challenge Sustainable Cities Fund and Global Engagement Fund.

Institutional Review Board Statement: The study was conducted according to the guidelines of the UCL Ethics Committee 2017.

Informed Consent Statement: Informed consent was obtained for all subjects involved in the study.

Data Availability Statement: Restrictions apply to the availability of the interview data. Data was obtained from third parties on the proviso the data was anonymized. Thus, data can only be made available with their consent.

Conflicts of Interest: The author declares no conflict of interest.

\section{References}

1. Camaren, P.; Swilling, M. Sustainable Resource Efficient Cities: Making It Happen; UNEP: Nairobi, Kenya, 2012.

2. Richter, B.D.; Abell, D.; Bacha, E.; Brauman, K.; Calos, S.; Cohn, A.; Siegfried, E. Tapped out: How can cities secure their water future? Water Policy 2013, 15, 335-363. [CrossRef]

3. Brinkley, C.; Birch, E.; Keating, A. Feeding cities: Charting a research and practice agenda toward food security. J. Agric. Food Syst. Community Dev. 2013, 3, 81-87. [CrossRef] 
4. Birol, F. World Energy Outlook; International Energy Agency: Paris, France, 2008; Volume 23, p. 329.

5. Boulding, K.E. The Economics of the Coming Spaceship Earth; Johns Hopkins University Press: Baltimore, MA, USA, 1966.

6. Camilleri, M.A. The circular economy's closed loop and product service systems for sustainable development: A review and appraisal. Sustain. Dev. 2019, 27, 530-536. [CrossRef]

7. Ellen MacArthur Foundation, SUN, McKinsey Centre for Business and Environment. Growth within: A Circular Economy Vision for a Competitive Europe; Ellen MacArthur Foundation: Cowes, UK, 2015.

8. Jackson, T. Prosperity without Growth: Foundations for the Economy of Tomorrow; Taylor \& Francis: Oxfordshire, UK, 2016.

9. Williams, J. Circular cities. Urban Stud. 2019, 56, 2746-2762. [CrossRef]

10. Williams, J. The role of spatial planning in transitioning to circular urban development. Urban Geogr. 2020, 41, 915-919. [CrossRef]

11. Williams, J. Circular Cities: A Revolution in Urban Sustainability; Routledge: London, UK, 2021.

12. Menikpura, S.N.M.; Sang-Arun, J.; Bengtsson, M. Integrated solid waste management: An approach for enhancing climate co-benefits through resource recovery. J. Clean. Prod. 2013, 58, 34-42. [CrossRef]

13. Yung, E.H.; Chan, E.H. Implementation challenges to the adaptive reuse of heritage buildings: Towards the goals of sustainable, low carbon cities. Habitat Int. 2012, 36, 352-361. [CrossRef]

14. Demuzere, M.; Orru, K.; Heidrich, O.; Olazabal, E.; Geneletti, D.; Orru, H.; Bhave, A.G.; Mittal, N.; Feliu, E.; Faehnle, M. Mitigating and adapting to climate change: Multi-functional and multi-scale assessment of green urban infrastructure. J. Environ. Manag. 2014, 146, 107-115. [CrossRef]

15. Hall, C.R.; Dickson, M.W. Economic, environmental, and health/well-being benefits associated with green industry products and services: A review. J. Environ. Hortic. 2011, 29, 96-103. [CrossRef]

16. Goonetilleke, A.; Liu, A.; Gardner, T. Urban Stormwater Reuse: An Agenda for Sustainable Development. Available online: https://sustainabledevelopment.un.org/content/documents/956312_Goonetilleke_URBAN\%20STORMWATER\%20REUSEAN\%20AGENDA\%20FOR\%20SUSTAINABLE\%20DEVELOPMENT.pdf (accessed on 1 May 2021).

17. Chaparro, L.; Terradas, J. Ecological Services of an Urban Forest in Barcelona, Barcelona: Centre de Recerca Ecoligica i Aplicacions Forestalls; Universtitat Untonma de Barcelona: Bellaterra, Spain, 2009.

18. Bolund, P.; Hunhammar, S. Ecosystem services in urban areas. Ecol. Econ. 1999, 29, 293-301. [CrossRef]

19. Villarreal, E.L.; Bengtsson, L. Response of a Sedum green-roof to individual rain events. Ecol. Econ. 2005, 25, 1-7. [CrossRef]

20. Roy, S.; Byrne, J.; Pickering, C. A systematic quantitative review of urban tree benefits, costs, and assessment methods across cities in different climatic zones. Urban For. Urban Green. 2012, 11, 351-363. [CrossRef]

21. Gómez-Baggethun, E.; Barton, D.N. Classifying and valuing ecosystem services for urban planning. Ecol. Econ. 2013, 86, 235-245. [CrossRef]

22. Wijkman, A.; Skånberg, K. The Circular Economy and Benefits for Society. Available online: https:/ /www.lagazettedescommunes. com/telechargements / etude-club-rome-eng.pdf (accessed on 1 May 2021).

23. Ellen MacArthur Foundation. Completing the Picture: How the Circular Economy Tackles Climate Change; EMF: Isle of Wight, UK, 2019.

24. Industrial Transformation 2050—Pathways to Net-Zero Emissions from EU Heavy Industry. Available online: https:// materialeconomics.com/publications/industrial-transformation-2050 (accessed on 1 May 2021).

25. Facchini, E.; Iacovidou, E.; Gronow, J.; Voulvoulis, N. Food flows in the United Kingdom: The potential of surplus food redistribution to reduce waste. J. Air Waste Manag. Assoc. 2018, 68, 887-899. [CrossRef]

26. Bullen, P.A.; Love, P.E. The rhetoric of adaptive reuse or reality of demolition: Views from the field. Cities 2010, 27, 215-224. [CrossRef]

27. Churkina, G. Carbon Cycle of Urban Ecosystems. In Carbon Sequestration in Urban Ecosystems; Lal, R., Augustin, B., Eds.; Springer: Dordrecht, The Netherlands, 2012. [CrossRef]

28. Velasco, E.; Roth, M.; Norford, L.; Molina, L.T. Does urban vegetation enhance carbon sequestration? Landsc. Urban Plan. 2016, 148, 99-107. [CrossRef]

29. Cheng, J.J.; Berry, P. Health co-benefits and risks of public health adaptation strategies to climate change: A review of current literature. Int. J. Public Health 2013, 58, 305-311. [CrossRef]

30. Vijayaraghavan, K.; Balasubramanian, R. Is biosorption suitable for decontamination of metal-bearing wastewaters? A critical review on the state-of-the-art of biosorption processes and future directions. J. Environ. Manag. 2015, 160, 283-296. [CrossRef]

31. Okvat, H.A.; Zautra, A.J. Community gardening: A parsimonious path to individual, community, and environmental resilience. Am. J. Community Psychol. 2011, 47, 374-387. [CrossRef]

32. Carrus, G.; Scopelliti, M.; Lafortezza, R.; Colangelo, G.; Ferrini, F.; Salbitano, F.; Agrimi, M.; Portoghesi, L.; Semenzato, P.; Sanesi, G. Go greener, feel better? The positive effects of biodiversity on the well-being of individuals visiting urban and peri-urban green areas. Landsc. Urban Plan. 2015, 134, 221-228. [CrossRef]

33. Ottelin, J.; Cetinay, H.; Behrens, P. Rebound effects may jeopardize the resource savings of circular consumption: Evidence from household material footprints. Environ. Res. Lett. 2020, 15, 104044. [CrossRef]

34. Maas, J.; Verheij, R.A.; de Vries, S.; Spreeuwenberg, P.; Schellevis, F.G.; Groenewegen, P.P. Morbidity is related to a green living environment. J. Epidemiol. Community Health 2009, 63, 967-973. [CrossRef] 
35. Stigsdotter, U.K.; Ekholm, O.; Schipperijn, J.; Toftager, M.; Kamper-Jørgensen, F.; Randrup, T.B. Health promoting outdoor environments-Associations between green space, and health, health-related quality of life and stress based on a Danish national representative survey. Scandinavian J. Public Health 2010, 38, 411-417. [CrossRef]

36. Hallegatte, S.; Ranger, N.; Mestre, O.; Dumas, P.; Corfee-Morlot, J.; Herweijer, C.; Wood, R.M. Assessing climate change impacts, sea level rise and storm surge risk in port cities: A case study on Copenhagen. Clim. Chang. 2011, 104, 113-137. [CrossRef]

37. Hoffimann, E.; Barros, H.; Ribeiro, A.I. Socioeconomic inequalities in green space quality and accessibility-Evidence from a Southern European city. Int. J. Environ. Res. Public Health 2017, 14, 916. [CrossRef]

38. Mears, M.; Brindley, P.; Maheswaran, R.; Jorgensen, A. Understanding the socioeconomic equity of publicly accessible greenspace distribution: The example of Sheffield, UK. Geoforum 2019, 103, 126-137. [CrossRef]

39. Wüstemann, H.; Kalisch, D. Towards a National Indicator for Urban Green Space Provision and Environmental Inequalities in Germany: Method and Findings (No. 2016-022). SFB 649 Discussion Paper. 2016. Available online: http://hdl.handle.net/10419/ 146191 (accessed on 5 May 2020).

40. Janssen, I.; Rosu, A. Undeveloped green space and free-time physical activity in 11 to 13 -year-old children. Int. J. Behav. Nutr. Phys. Act. 2015, 12, 26. [CrossRef]

41. Nawrath, M.; Kowarik, I.; Fischer, L.K. The influence of green streets on cycling behavior in European cities. Landsc. Urban Plan. 2019, 190, 103598. [CrossRef]

42. Zhang, X.; Melbourne, S.; Sarkar, C.; Chiaradia, A.; Webster, C. Effects of green space on walking: Does size, shape and density matter? Urban Stud. 2020, 0042098020902739. [CrossRef]

43. Sallis, J.F.; Adlakha, D.; Oyeyemi, A.; Salvo, D. An international physical activity and public health research agenda to inform coronavirus disease-19 policies and practices. J. Sport Health Sci. 2020, 9, 328-334. [CrossRef]

44. Simpson, R.J.; Katsanis, E. The immunological case for staying active during the COVID-19 pandemic. Brain Behav. Immunol. 2020, 87, 6-7. [CrossRef]

45. Slater, S.J.; Christiana, R.W.; Gustat, J. Recommendations for Keeping Parks and Green Space Accessible for Mental and Physical Health During COVID-19 and Other Pandemics. Prev. Chronic Dis. 2020, 17, 200-204. [CrossRef]

46. Oberndorfer, E.; Lundholm, J.; Bass, B.; Coffman, R.R.; Doshi, H.; Dunnett, N.; Gaffin, S.; Köhler, M.; Liu, K.K.; Rowe, B. Green roofs as urban ecosystems: Ecological structures, functions, and services. BioScience 2007, 57, 823-833. [CrossRef]

47. Alexander, C.; Smaje, C. Evaluating third sector reuse organizations in the UK: Case-studies and analyzis of furniture reuse schemes. Resour. Conserv. Recycl. 2008, 52, 719-730. [CrossRef]

48. Pesch, U.; Spekkink, W.; Quist, J. Local sustainability initiatives: Innovation and civic engagement in societal experiments. Eur. Plan. Stud. 2019, 27, 300-317. [CrossRef]

49. Coelho, F.C.; Coelho, E.M.; Egerer, M. Local food: Benefits and failings due to modern agriculture. Sci. Agric. 2018, 75, 84-94. [CrossRef]

50. Lipp, J.; McMurtry, J.J. Benefits of Renewable Energy Co-Operatives: Summary of Literature Review from the Measuring the Co-Operative Difference Research Network; Measuring the Co-Operative Difference Research Network: Toronto, ON, Canada, 2015.

51. Heras-Saizarbitoria, I.; Sáez, L.; Allur, E.; Morandeira, J. The emergence of renewable energy cooperatives in Spain: A review. Renew. Sustain. Energy Rev. 2018, 94, 1036-1043. [CrossRef]

52. Dobson, S.; Jorgensen, A. Increasing the resilience and adaptive capacity of cities through entrepreneurial urbanism. Int. J. Glob. Small Bus. 2014, 6, 149-162. [CrossRef]

53. Stevens, Q.; Dovey, K. Pop-ups and Public Interests: Agile Public Space in the Neoliberal City. In The Palgrave Handbook of Bottom-Up Urbanism; Arefi, M., Kickert, C., Eds.; Palgrave Macmillan: Cham, Switzerland, 2019. [CrossRef]

54. Wolch, J.R.; Byrne, J.; Newell, J.P. Urban green space, public health, and environmental justice: The challenge of making cities 'just green enough'. Landsc. Urban Plan. 2014, 125, 234-244. [CrossRef]

55. Frayne, B.; McCordic, C.; Shilomboleni, H. The Mythology of Urban Agriculture. In Rapid Urbanisation, Urban Food Deserts and Food Security in Africa; Crush, J., Battersby, J., Eds.; Springer: Cham, Switzerland, 2016. [CrossRef]

56. Stahel, W.R. The circular economy. Nature 2016, 531, 435-438. [CrossRef] [PubMed]

57. Bastein, A.G.T.M.; Roelofs, E.; Rietveld, E.; Hoogendoorn, A. Opportunities for a Circular Economy in the Netherlands; TNO: Delft, The Netherlands, 2013; pp. 1-13. ISBN 978-90-5986-436-8.

58. Burger, M.; Stavropoulos, S.; Ramkumar, S.; Dufourmont, J.; van Oort, F. The heterogeneous skill-base of circular economy employment. Res. Policy 2019, 48, 248-261. [CrossRef]

59. Chateau, J.; Mavroeidi, E. The jobs potential of a transition towards a resource efficient and circular economy. OECD Work. Pap. 2020, 167. [CrossRef]

60. Biber-Freudenberger, L.; Ergeneman, C.; Förster, J.J.; Dietz, T.; Börner, J. Bioeconomy futures: Expectation patterns of scientists and practitioners on the sustainability of bio-based transformation. Sustain. Dev. 2020, 28, 1220-1235. [CrossRef]

61. Lewandowski, I. Bioeconomy: Shaping the Transition to a Sustainable, Biobased Economy; Springer Nature: Basingstoke, UK, 2018. [CrossRef]

62. Knuth, S. Seeing Green in San Francisco: City as Resource Frontier. Antipode 2016, 48, 626-644. [CrossRef]

63. Ten Brink, P.; Mutafoglu, K.; Schweitzer, J.-P.; Underwood, E.; Tucker, G.; Russi, D.; Howe, M.; Maréchal, A.; Olmeda, C.; Pantzar, M.; et al. Natura 2000 and Jobs: Scoping Study Executive Summary; Institute for European Environmental Policy: Brussels, Belgium, 2017. 
64. Hetemäki, L.; Hanewinkel, M.; Muys, B.; Ollikainen, M.; Palahí, M.; Trasobares, A.; Aho, E.; Ruiz, C.N.; Persson, G.; Potoćnik, J. Leading the Way to a European Circular Bioeconomy Strategy; European Forest Institute: Joensuu, Finland, 2017; Volume 5, ISBN 978-952-5980-40-0.

65. Németh, J.; Langhorst, J. Rethinking urban transformation: Temporary uses for vacant land. Cities 2014, 40, 143-150. [CrossRef]

66. Aksamija, A. Regenerative design and adaptive reuse of existing commercial buildings for net-zero energy use. Sustain. Cities Soc. 2016, 27, 185-195. [CrossRef]

67. Madanipour, A. Temporary use of space: Urban processes between flexibility, opportunity and precarity. Urban Stud. 2018, 55, 1093-1110. [CrossRef]

68. Bishop, P.; Williams, L. The Temporary City; Routledge: London, UK, 2012; ISBN 978-415-67055-5.

69. Williams, J. Circular cities: Challenges to implementing looping actions. Sustainability 2019, 11, 423. [CrossRef]

70. Bastein, A.G.T.M.; Verstraeten-Jochemsen, J.N.; Rietveld, E.; Hauck, M.; Frijters, E.; Klijn, O.; Driessen, B. Circular Amsterdam. A Vision and Action Agenda for the City and Metropolitan Area; TNO: Delft, The Netherlands, 2016.

71. Atkins Global. Enabling the Olympic Park 2012. Available online: https:/ /www.atkinsglobal.com/en-gb/media-centre/features/ enabling-olympic-park (accessed on 24 April 2020).

72. Marie de Paris Circular Economy Plan Paris Adopted 2017; Marie de Paris: Paris, France, 2017.

73. Williams, J.; Bartlett School of Planning, University College London, London, UK. Interview with Public Administrator Involved in the Creation of the Circular Strategy for PARIS (Interview 6), Paris, France, 2018.

74. Williams, J.; Bartlett School of Planning, University College London, London, UK. Interview with Engineering Consultant Working for WSP Consulting Sweden with Responsibility for Delivering Sustainable Systems in Stockholm Royal Seaport (Interview 20), Stockholm, Sweden, 2017.

75. Brick, K. Follow Up of Environmental Impact in Hammarby Sjöstad; Grontmij AB: Stockholm, Sweden, 2008.

76. Pandis, S.; Johanssen, S.; Brandt, N. The potential of the infrastructural system of Hammarby Sjöstad in Stockholm. Energy Policy 2013, 59, 716-726. [CrossRef]

77. Williams, J.; Bartlett School of Planning, University College London, London, UK. Interview with Waste Consultant Working for a Major Waste Management Company (Interview 1), Amsterdam, The Netherlands, 2019.

78. Williams, J.; Bartlett School of Planning, University College London, London, UK. Interview with Strategic Officer Engaged in Delivering the Circular Innovation Program (Interview 3), Amsterdam, The Netherlands, 2019.

79. Williams, J.; Bartlett School of Planning, University College London, London, UK. Interview with Representative of Edible Lambeth, a Community Food Growing Network (Interview 14), London, UK, 2018.

80. Williams, J.; Bartlett School of Planning, University College London, London, UK. Interview with Representative of Capital Growth, London's Food Growing Network (Interview 15), London, UK, 2018.

81. Williams, J.; Bartlett School of Planning, University College London, London, UK. Interview with Representative of Loughborough Junction, a Community Farm in Brixton (Interview 16), London, UK, 2018.

82. Williams, J.; Bartlett School of Planning, University College London, London, UK. Interview with Representative of Food Surplus Network Organized by Waste and Resources Action Program (Interview 17), London, UK, 2018.

83. Williams, J.; Bartlett School of Planning, University College London, London, UK. Interview with Energy Consultant for Fortum the Energy Company in Stockholm with the Responsibility for Delivering Ecocycles (Interview 22), Stockholm, Sweden, 2017.

84. Regional Authority of Paris Regional Master Plan-Greater Paris Region 2030 (SDRIF); Regional Authority of Paris: Paris, France, 2013.

85. Williams, J. Can low carbon city experiments transform the development regime? Futures 2016, 77, 80-96. [CrossRef]

86. Van der Hoek, J.P.; de Fooij, H.; Struker, A. Wastewater as a resource: Strategies to recover resources from Amsterdam's wastewater. Resour. Conserv. Recycl. 2016, 113, 53-64. [CrossRef]

87. Port of Amsterdam. Amsterdam Ready for the Bio-Based Port of Amsterdam Economy; Port of Amsterdam: Amsterdam, The Netherlands, 2018.

88. Williams, J.; Bartlett School of Planning, University College London, London, UK. Interview with Circular Economy Consultant at TNO Netherlands an Organization for Applied Scientific Research (Interview 2), Amsterdam, The Netherlands, 2019.

89. Williams, J.; Bartlett School of Planning, University College London, London, UK. Interview with an Environmental Service Consultant Working Based in De Ceuvel (Interview 4), Amsterdam, The Netherlands, 2019.

90. Williams, J.; Bartlett School of Planning, University College London, London, UK. An Interview with a Sustainability Expert Advising the Olympic Development Agency and London Legacy Development Corporation on the Development and Ongoing Management of the QEOP Site (Interview 8), London, UK, 2018.

91. Williams, J.; Bartlett School of Planning, University College London, London, UK. An Interview with a Strategic Planner at Stockholm City Council Responsible for Hammarby Sjostad and Stockholm Royal Seaport (Interview 19), Stockholm, Sweden, 2017.

92. Williams, J.; Bartlett School of Planning, University College London, London, UK. An Interview with a Representative of Transition Town Brixton a Community Interest Company (Interview 11), London, UK, 2019.

93. Williams, J.; Bartlett School of Planning, University College London, London, UK. An Interview with a Representative of Pop Brixton, a Social Enterprise in Brixton (Interview 13), London, UK, 2019.

94. Williams, J.; Bartlett School of Planning, University College London, London, UK. An Interview with a Representative of Loughborough Junction, a Community Farm in Brixton (Interview 16), London, UK, 2019. 
95. Williams, J.; Bartlett School of Planning, University College London, London, UK. An Interview with a Representative of Remade Brixton a Social Enterprise in Brixton Linked to the Remakery (Interview 18), London, UK, 2019.

96. Williams, J.; Bartlett School of Planning, University College London, London, UK. An Interview with an Economic Advisor in the Economic Development Team, London Borough of Lambeth (Interview 10), London, UK, 2019.

97. Williams, J.; Bartlett School of Planning, University College London, London, UK. An Interview with a Consultant Working for a Social Enterprise Engaged in Implementing Temporary Uses in Lambeth (Interview 12), London, UK, 2019.

98. Williams, J.; Bartlett School of Planning, University College London, London, UK. An Interview with a Real Estate Expert from a Cooperative in Temporary Urban Planning in Paris (Interview 7); Paris, France, 2018.

99. Williams, J.; Bartlett School of Planning, University College London, London, UK. An Interview with a Construction Waste Consultant for Veolia Paris (Interview 5), Paris, France, 2018.

100. Williams, J.; Bartlett School of Planning, University College London, London, UK. An Interview with an Engineering Consultant Working for WS Atkins (Global Engineering consultancy) on Projects for the QEOP site (Interview 9), London, UK, 2019.

101. Mitchell, P. Employment and the circular economy-Job Creation through resource efficiency in London. In Report Produced by WRAP for the London Sustainable Development Commission, the London Waste and Recycling Board and the Greater London Authority; Greater London Auhtority: London, UK, 2015.

102. London Waste and Recycling Board. London's Circular Economy Route Map. Available online: https://relondon.gov.uk/ circulareconomy (accessed on 1 May 2021).

103. Williams, J.; Bartlett School of Planning, University College London, London, UK. An interview with an Architectural Consultant Working for SWECO Consulting SE with Responsibility for Delivering Ecocycles in Hammarby Sjostad and Stockholm Royal Seaport (Interview 21), Stockholm, Sweden, 2017. 